\title{
The INTERREG Italy-Croatia Joint_SECAP Project: A Collaborative Approach for Adaptation Planning
}

\author{
Timothy Daniel Brownlee ${ }^{1, *}$, Chiara Camaioni ${ }^{1}$, Stefano Magaudda ${ }^{2}$, Stefano Mugnoz ${ }^{1}$ and Piera Pellegrino ${ }^{1, *}$ \\ 1 School of Architecture and Design (SAAD), University of Camerino, Viale Della Rimembranza, Snc, \\ 63100 Ascoli Piceno, Italy; chiara.camaioni@unicam.it (C.C.); stefano.mugnoz@unicam.it (S.M.) \\ 2 Department of Civil, Constructional and Environmental Engineering (DICEA), Sapienza University of Rome, \\ 00184 Rome, Italy; stefano.magaudda@uniroma1.it \\ * Correspondence: timothy.brownlee@unicam.it (T.D.B.); piera.pellegrino@unicam.it (P.P.)
}

Citation: Brownlee, T.D.; Camaioni, C.; Magaudda, S.; Mugnoz, S.; Pellegrino, P. The INTERREG Italy-Croatia Joint_SECAP Project: A Collaborative Approach for Adaptation Planning. Sustainability 2022, 14, 404. https://doi.org/ $10.3390 /$ su14010404

Academic Editor: Baojie He

Received: 30 November 2021 Accepted: 27 December 2021 Published: 31 December 2021

Publisher's Note: MDPI stays neutral with regard to jurisdictional claims in published maps and institutional affiliations.

Copyright: (c) 2021 by the authors Licensee MDPI, Basel, Switzerland. This article is an open access article distributed under the terms and conditions of the Creative Commons Attribution (CC BY) license (https:// creativecommons.org/licenses/by/ $4.0 /)$.
Abstract: With regard to the scientific debate which highlights the potential of joint climate planning, there are few concrete experiences in Europe where this approach has been applied. This contribution focuses on critical methodological and application aspects of the processes underlying the development of Joint Plans for Sustainable Energy and Climate in the supra-municipal area as emerged from the direct participation of the authors in the Joint_SECAP project funded by the Interreg Italia-Croatia programme. This paper presents a comparative analysis of nine case studies in Italy and Croatia with a focus on fundamental aspects of the planning process: the governance model, shared knowledge framework, risk and vulnerability assessment, and participatory process. The analysis and comparison of the Joint_SECAP experiences confirm that joint climate planning, developed in the framework of the European Covenant of Mayors (CoM) initiative, is effective for creating synergy between local authorities and for defining and implementing strategies and actions for adaptation to the territorial scale. Finally, the research indicates some recommendations to overcome the barriers that impede the spread and effectiveness of this approach to climate planning. In particular, it highlights the need to enhance collaboration between local authorities, regions, and CoM coordinators.

Keywords: climate change; supra-municipal approach; vulnerability and risk assessment; stakeholder involvement; governance; adaptation measures

\section{Introduction}

In the last decade, the European Commission has made significant efforts to promote sustainable energy and climate policies in member states (from the 2008 Climate and Energy Package and Directives 2009/28/EC, 2010/31/EU, and 2012/27/EU to the 2021 EU Strategy on Adaptation to Climate Change). The 2021 Strategy vision is that "in 2050, the EU will be a climate-resilient society, fully adapted to the unavoidable impacts of climate change", thanks to a "smarter, swifter and more systemic [adaptation]" and by "stepping up international action". This can be translated into "improving knowledge and data; supporting policy development and climate risk management at all levels; and accelerating adaptation actions" [1].

The European Commission supports planning and implementation of local adaptation projects and launched an adaptation support facility under the EU Covenant of Mayors (CoM) [2].

In 2015, the CoM evolved into the Covenant of Mayors for Climate and Energy, intensifying the objective of mitigation and integrating two other pillars: adaptation and access to energy. To translate commitments into actions, local authorities signed a voluntary commitment to develop participation in the Sustainable Energy and Climate Action Plan (SECAP) within two years, with the participation of society and supported by tools to monitor and assess the results. The plan includes a comprehensive set of policies and 
actions aimed at achieving the climate mitigation and adaptation goals [3,4], and is based on an assessment of the risks and vulnerabilities induced by climate change.

Among the tools used to support local authorities, the CoM officially introduced the possibility of preparing a joint SECAP in 2012 as a result of feedback and recommendations from its signatories [5], aimed at aligning the action plan development process with the needs expressed by local authorities. Joint SECAPs are defined as follows: "A joint SECAP refers to a plan that is carried out collectively by a group of neighbouring local authorities. This means that the group engages in building a common vision, preparing an emission inventory, assessing climate change impacts and defining a set of actions to be implemented both individually and jointly in the concerned territory. The joint SECAP aims at fostering institutional cooperation and joint approaches among local authorities operating in the same territorial area" [5]. A joint approach goes beyond the administrative boundaries of neighbouring local authorities and can potentially achieve more effective results than isolated SECAPs [5].

In recent years, the scientific framework of reference has highlighted that climate strategies can benefit from joint approaches, and that finding working methods based on systematizing co-benefits is an urgent task [6]. Climate adaptation certainly represents a growing trend, but it also requires a rethinking of the tools and solutions generally adopted in planning practice [7]. As many have highlighted, to address the impacts of climate change, especially in coastal areas, it becomes increasingly necessary to implement processes based on collaborative planning, the creation of networks, and the identification of decision-making support tools and systems to develop effective strategies and measures to make territories climate-proof [8-10]. Indeed, it has been observed that among the elements that can contribute more effectively to adaptation, not only the proposed measures should be integrated into functionally linked policy documents and processes [11], but also that common attributes of adaptation initiatives reported to be effective such as resource sharing, collective decision-making, and mutually beneficial outcomes [12].

Several studies regarding SECAPs have described the difficulties in effectively applying tools aimed at addressing the climate, which are often due to the lack of financial, technical, and human resources, as well as the ability to actively and effectively involve the population [13,14]. Small municipalities necessarily need to use substantial resourcesoften not aligned with their available budget-to comply with the commitments of the CoM and draw up a Sustainable Energy Action Plan (SEAP) or a SECAP [14,15]. In addition, administrations encounter several critical issues at the start of planning processes caused by the lack of integration between plans operating on different levels [16]. According to the CoM Report in May 2017, most of the CoM signatories (90\%) are small and medium-sized towns (SMSTs), and more than $70 \%$ of these are from Italy, where a joint or collaborative approach may be suitable due to the small size of most of the municipalities [2,5]. SMSTs with fewer resources [17], both in economic terms and in terms of qualified personnel, may find it challenging to define suitable tools to tackle climate change effectively, so access to funds becomes crucial for implementing effective local climate change action $[4,18,19]$.

Other critical aspects regard the fragmentation of skills among different sectors of the public administration and the absence of coordination among them [14].

The aggregation of different municipalities into homogeneous areas involved in the process of developing joint SECAPs can benefit from economies of scale as in public procurement and can easily overcome problems arising from the lack of human and financial resources [14,19].

In addition, joint governance agreements, particularly between small municipalities, would allow administrations to identify opportunities connected to the adoption of development strategies and become economically more attractive [20], facilitating the continuity of long-term actions and reducing the influence of political changes [13].

Another aspect that emerges from various studies in the scientific framework and in comparing different climate planning experiences is the strong interrelation between collab- 
orative governance and stakeholder involvement in terms of both institutional consultation and consultation/co-decision of mitigation and adaptation interventions [21,22].

In preparing climate planning tools, the recent study by Jekabsone et al. [18] highlighted that "where stakeholder involvement is used already in the early stages of adaptation strategy development, is considered helpful in gaining public acceptance and trust. When stakeholders are involved in identifying risks and vulnerabilities, it is much easier to justify the need for actions".

The scientific debate, which highlights the potential of joint climate planning, especially in small-medium municipalities, shows that there are few concrete experiences in Italy and Croatia that have been applied using this approach. To date (mid-2021), only 15 joint SECAPs have been approved by the CoM. In addition, these joint climate-planning experiences in small-medium municipalities have still not been developed critically, as evidenced by the low number of related scientific articles, documents, and interviews. Moreover, the periodic monitoring reports expected by the CoM every two years after the action plan is presented have still not been prepared and published officially, since they are recently drafted tools [13]. The question is therefore why, when faced with acquired awareness regarding the benefits that a joint approach to climate adaptation may involve and which the literature has highlighted, have these experiences rarely been published or studied? What are the critical aspects in the process tied to implementing the plans and what may be some possible solutions to improve governance and make these tools more effective (more widespread and easier to access)?

In this sense, this paper provides a critical contribution related to a real recent experience that included moments of verification with the support of technicians and administrators, even through the direct participation of the authors at capacity-building events and through the results of a questionnaire administered to coordinators at the end of the project.

The Joint_SECAP project (Joint Strategies for Climate Change Adaptation in Coastal Areas), financed by the Interreg Italy-Croatia programme, with its 9 areas, serves as an opportunity to test this method on territorial areas composed of several small-medium municipalities. The transnational experience gained by the Joint_SECAP partners offers a decisive contribution focusing on the strengths and weaknesses of joint climate planning on contiguous territories and, namely, on a broader scale than the municipal area, following the indications in the Covenant of Mayors [5].

In particular, this paper addresses four key aspects of the climate-planning process:

1. the collaborative governance and coordination model;

2. synergies between the risk and vulnerability assessment and spatial planning;

3. the involvement of key players and stakeholders;

4. joint actions for adaptation on the supra-municipal scale.

\section{INTERREG Italy-Croatia Joint_SECAP Project}

The Joint_SECAP project (Joint Strategies for Climate Change Adaptation in Coastal Areas), was financed by the Interreg Italy-Croatia programme and conducted between 2019 and 2021. The project aimed to build a common method to define joint sustainable energy and climate action plans (SECAPs) focused on sharing knowledge on climate change adaptation and mitigation measures for coastal areas of the Adriatic. The collaboration consisted of eight Italian and Croatian partners who identified at least one pilot area, for nine altogether, comprising a set of contiguous municipalities (Figure 1) where the process of defining joint adaptation actions to be included in a joint SECAP was tested in collaboration with local administrations (PAs). Only the Abruzzo Region identified two pilot areas: one coastal and one further inland. 


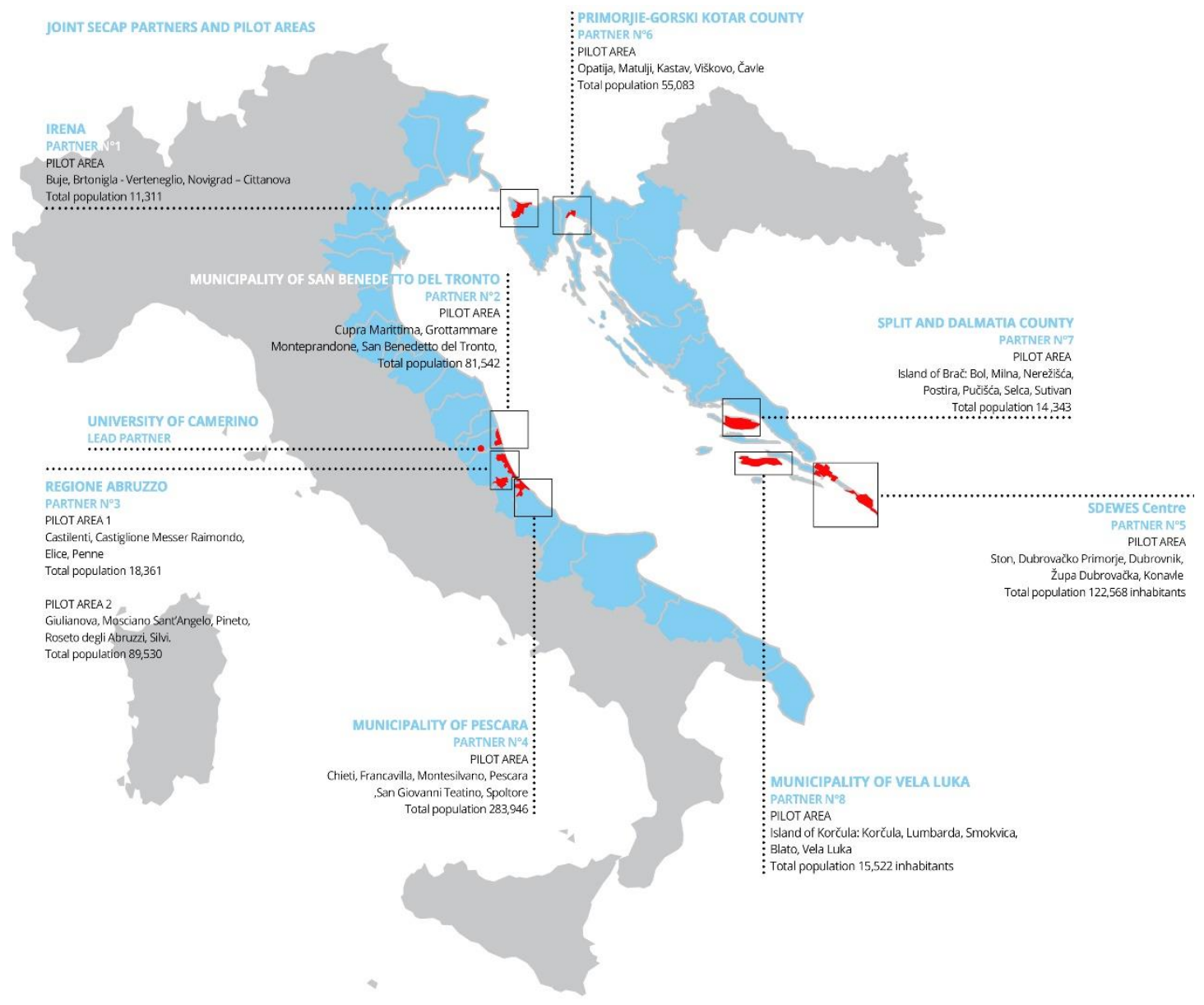

Figure 1. Pilot areas of the Joint_SECAP project.

The main objective of the project was to improve climate change monitoring and the planning of adaptation measures to tackle specific effects in the area of cooperation. Another goal of the project was to increase the knowledge of local authorities and their capacity regarding climate adaptation in coastal areas, enabling them to adopt a supramunicipal approach to improve the performance of these measures in pursuit of European policies and targets.

The Joint_SECAP project follows the implementation phases in preparing a Joint SECAP as requested the by the CoM, and it tests and studies several steps involving innovative aspects such as:

The use of the Strategic Environmental Assessment (SEA) to assess internal and external consistency;

The selection of a suitable scenario through a strong participatory process with the main stakeholders to compare scenario 0 and the optimal scenario;

The identification of a joint coordinator for each pilot area, a pivotal figure to foster horizontal collaboration between the various offices and sectors of the entities involved;

The development of a specific web platform released during the project as a database of joint adaptation and mitigation actions defined by each partner and a tool for disseminating the results.

In this framework, the paper aims to provide helpful support for SMSTs that decide to identify a set of adaptation measures for their territory or establish a joint SECAP and undertake a joint climate planning experience. 


\section{Materials and Methods}

With regard to the field of research, which aims to understand and analyse phenomena and governance practices, the method of comparative analysis was chosen as the most appropriate for investigating the case studies regarding the knowledge of processes rather than individual products, and to understand the overall context rather than specific variables.

As a reference, the qualitative analysis of the case studies relied on the method applied for sociological research by Robert K. YIN (1994), based on which different data-collection methods are used: documents, archival records, interviews, direct and participatory observation, and concrete elements [23]. More specifically, to analyse the case studies, the following sources and data-collection methods were used: deliverables from the Joint_SECAP project, participatory observation in workshops, focus groups, capacity-building events, questionnaires, and interviews.

To understand and analyse phenomena and governance practices, the classical datacollection methods were accompanied by an investigation in the field, observing some consultation activities and the involvement of key players and interest holders. The research method consisted of continuous comparison and verification, not only with the project partners, but also with technical consultants and local players involved in the various phases of drafting the SECAPs.

\subsection{Criteria for Data Collection}

The method of investigation applied by the authors intended to highlight not only the strengths highlighted in the project deliverables [24,25], but also the critical aspects emerging from collaboration with public and private subjects.

Concerning the pilot area related to the Interreg Joint_SECAP project, the partners [24] followed a shared methodological path based on the indications of the CoM for defining joint adaptation actions for a district composed of several municipalities to be included in a SECAP. Although the plans have not yet been officially released for all the Interreg Italy-Croatia Joint_SECAP project case studies (Table 1), the methodological processes and actions identified by the partners are suitable for the comparative analysis of this contribution due to the exhaustiveness of the information relating to the process to prepare the joint adaptation action. Each partner draws up the official project deliverables.

The authors participated in the Joint_SECAP project, which made it possible to observe directly and carry out the different phases of the process in the field, leading to an understanding of the critical steps in the governance process and highlighting its strengths and weaknesses. The research group also participated in events and meetings between the project partners and collected information and suggestions directly from the subjects coordinating the activities in the various pilot areas.

After the planning and programming process, each partner filled in a questionnaire to highlight the critical aspects and strengths of the various joint climate planning experiences. The questions useful for the comparative evaluation posed to the project partners were:

- Vulnerability and risk methodology: (i) Was the method used to identify vulnerabilities and risks easy to use? Are there any corrections to suggest? (ii) Was the knowledge and data available on the local level for the application of the method sufficient? If not, what strategies were implemented to overcome these limits?

- Construction of scenarios and preliminary scoping report: (i) Was the method used to build the scenarios effective? (ii) Was the focus groups formula successful in moving from the ' 0 ' scenario to the optimal scenario? (iii) Do you think that the preliminary scoping report contributed to formulating the shared optimal scenario? (iv) Can the SEA (Strategic Environmental Assessment) process in its entirety constitute an aid to constructing a joint SECAP? 
Table 1. Target areas of the Joint_SECAP project.

\begin{tabular}{|c|c|c|c|c|c|c|}
\hline \multirow{2}{*}{$\begin{array}{c}\text { Partner Joint_SECAP } \\
\text { Project }\end{array}$} & \multirow{2}{*}{ NUTS 1} & \multirow{2}{*}{ NUTS 2} & \multicolumn{4}{|l|}{ Pilot Area } \\
\hline & & & Municipalities & No. & $\mathrm{km}^{2}$ & Inhab. \\
\hline San Benedetto del Tronto & IT & Marche & $\begin{array}{l}\text { San Benedetto del Tronto, Grottammare, } \\
\text { Cupra Marittima, Monteprandone }\end{array}$ & 4 & 86.65 & 81,785 \\
\hline Pescara & IT & Abruzzo & $\begin{array}{l}\text { Pescara, Chieti, Montesilvano, Francavilla } \\
\text { al Mare, Spoltore, San Giovanni Teatino }\end{array}$ & 6 & 193.8 & 282,708 \\
\hline $\begin{array}{l}\text { Abruzzo Region } \\
\text { Target Area } 1\end{array}$ & IT & Abruzzo & $\begin{array}{c}\text { Penne, Elice, Castilenti, Castiglione Messer } \\
\text { Raimondo }\end{array}$ & 4 & 158 & 18,631 \\
\hline $\begin{array}{l}\text { Abruzzo Region } \\
\text { Target Area } 2\end{array}$ & IT & Abruzzo & $\begin{array}{l}\text { Giulianova, Roseto degli Abruzzi, Pineto, } \\
\text { Silvi, Mosciano S.Angelo }\end{array}$ & 5 & 185.75 & 89,530 \\
\hline $\begin{array}{l}\text { Istrian Regional Energy } \\
\text { Agency (IRENA) }\end{array}$ & $\mathrm{HR}$ & Istria & $\begin{array}{c}\text { City of Buje-Buie, City of } \\
\text { Novigrad-Cittanova, } \\
\text { Municipality Brtonigla }\end{array}$ & 3 & 163.4 & 11,311 \\
\hline SDEWES Centre & $\mathrm{HR}$ & $\begin{array}{l}\text { Dubrovnik- } \\
\text { Neretva }\end{array}$ & $\begin{array}{l}\text { Dubrovnik, Konavle, Župa dubrovačka, } \\
\text { Dubrovačko primorje, Ston }\end{array}$ & 5 & 742.03 & 65,327 \\
\hline $\begin{array}{l}\text { Primorje-Gorski Kotar } \\
\text { County (PGKC) }\end{array}$ & $\mathrm{HR}$ & $\begin{array}{l}\text { Primorje- } \\
\text { Gorski } \\
\text { Kotar }\end{array}$ & Kastav, Opatija, Čavle, Matulji, Viškovo & 5 & 357 & 55,010 \\
\hline Split Dalmatia & HR & $\begin{array}{c}\text { Split- } \\
\text { Dalmatia }\end{array}$ & $\begin{array}{l}\text { Supetar, Sutivan, Bol, Milna, Selca, } \\
\text { Nerežišća, Postira, Pučišća }\end{array}$ & 8 & 396 & 14,343 \\
\hline Vela Luka & HR & $\begin{array}{l}\text { Dubrovnik- } \\
\text { Neretva }\end{array}$ & $\begin{array}{l}\text { Vela Luka, Blato, Smokvica, } \\
\text { Lumbarda, Korčula }\end{array}$ & 5 & 276 & 15,522 \\
\hline
\end{tabular}

\subsection{Criteria for Comparison}

The criteria for comparing the Joint_SECAP case studies were defined starting from the project methodology (Figure 2) [24,25], which specifies the steps and key points of the collaborative governance process. In particular, the interesting aspect on which the analysis focuses concerns the methods for managing a joint and collaborative planning process.

This contribution observes and compares four key aspects of the process implemented by the partners during the project:

1. the collaborative governance and coordination model;

2. synergies between the risk and vulnerability assessment and spatial planning;

3. the involvement of key players and stakeholders;

4. joint actions on the supra-municipal scale in terms of adaptation.

The comparison and evaluation criteria for the first point concern:

- The existence of climate planning tools and/or CoM plans (SEAP or SECAP) active on the local scale. This parameter is one strategic criterion for evaluating the capacity of the territory to address the planning process in terms of organizational and technical skills and the involvement of local actors.

- The presence of a territorial CoM Territorial Coordinator.

- The role of the lead municipality as coordinator of the joint SECAP, highlighting the organizational structure of the managing board and external support for technical activities. It enables understanding the promoter's ability to develop the plan with internal resources and make both technical and political decisions to develop it. This comparison criterion is also used to assess the ability of PAs to internally manage a complex, unusual process and assess consultants' level of involvement.

- Mapping of stakeholders and key players, which allows for an understanding of whether the key players who can favour development and implementation of the plan have been involved since the phase to set out the process. 


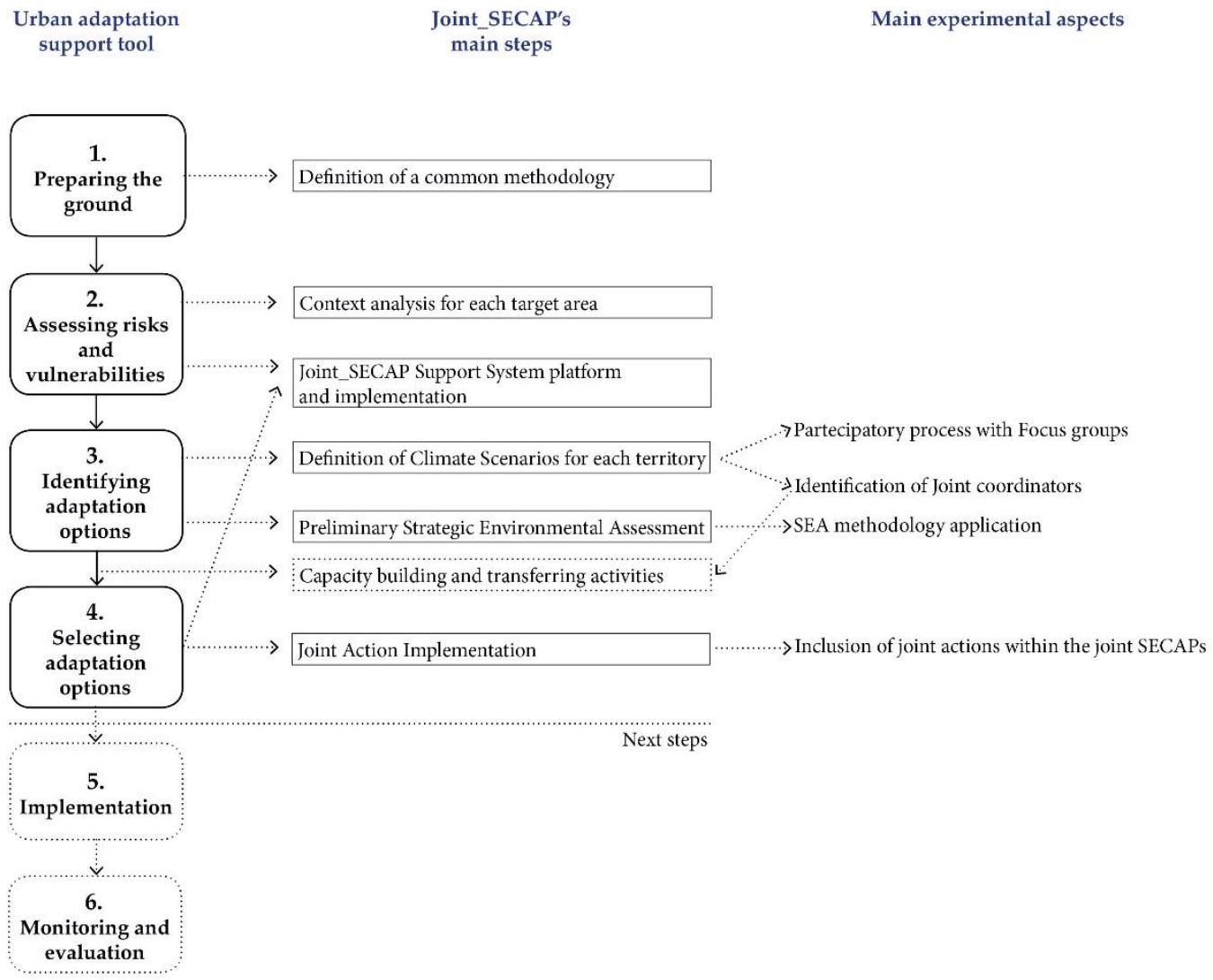

Figure 2. Phases of the Joint_SECAP project and its innovations in the CoM approach.

The comparison criteria for the second point regard:

- The regulatory framework and available dataset. This enables an understanding of the completeness of the cognitive and planning framework helpful in developing the action plan. In particular, it can be helpful for understanding whether hazard and risk maps already exist and the level of detail of climate data (national, regional, local).

- Synergies between climate planning and planning tools on various scales within the application of the SEA. In the process, the SEA was applied experimentally to verify the external and internal consistency.

- Results of the risk and vulnerability assessment in terms of documents: risk table, hazard maps, risk maps. Carrying out a local risk and vulnerability assessment is a complex procedure that requires technical skills and adequate data to use quantitative assessment tools.

The Joint_SECAP project method provides for a participatory process to involve stakeholders in sharing future intervention scenarios and identifying joint actions to be included in the plan. The evaluation criteria used for the participatory process and the involvement of key players and stakeholders are:

- Key players involved in the participation process. This criterion enables an understanding of the key actors indispensable to make climate planning effective and sustainable and the requirements for guaranteeing multilevel governance.

- The level of involvement of the actors in drafting the action plan. This criterion allows for an understanding of the quality and effectiveness of the participatory process for evaluating and selecting priority actions to achieve the plan's objectives (non-institutional participation and community involvement).

- Methods of stakeholder involvement and phases in the participatory process.

The following criteria were selected to understand the level of complexity and completeness of the proposed joint adaptation actions and concerns: 
- Type of actions (tangible or intangible);

- The answer to previously identified climate hazards with the risk and vulnerability assessment in terms of joint adaptation actions.

3. Results

\subsection{Collaborative Governance and Coordination Model}

For the definition of adaptation measures to be included in a joint plan prior to the Joint_SECAP project, most local administrations involved in the pilot areas already had an awareness of the objectives set by the CoM. Sixty-seven percent of cases (30 out of 45) had already drawn up an autonomous SEAP, of which $36 \%$ (16 out of 45 ) were in Italy and $31 \%$ (14 out of 45) were in Croatia (Table 2).

Table 2. Coordination, managing board, and tools in each pilot area.

\begin{tabular}{|c|c|c|c|c|c|c|}
\hline \multirow{2}{*}{$\begin{array}{c}\text { Partner } \\
\text { Joint_SECAP } \\
\text { Project } \\
\end{array}$} & \multirow{2}{*}{$\begin{array}{c}\text { SEAP or SECAP } \\
\text { (for Each Municipality } \\
\text { of Pilot Area) }\end{array}$} & \multirow{2}{*}{ CTC } & \multirow{2}{*}{ Joint_SECAP Coordinator } & \multicolumn{2}{|c|}{ Managing Board } & \multirow{2}{*}{$\begin{array}{l}\text { External } \\
\text { Support }\end{array}$} \\
\hline & & & & Political & Technical & \\
\hline $\begin{array}{l}\text { San Benedetto del } \\
\text { Tronto }\end{array}$ & 1 out of 4 & & $\begin{array}{l}\text { Municipality of San } \\
\text { Benedetto del Tronto }\end{array}$ & $\mathrm{x}$ & $x$ & $\mathrm{x}$ \\
\hline Pescara & 6 out of 6 & $\begin{array}{l}\text { Abruzzo } \\
\text { Region }\end{array}$ & Municipality of Pescara & $x$ & $\mathrm{x}$ & $\mathrm{x}$ \\
\hline $\begin{array}{c}\text { Abruzzo } \\
\text { Region-Area } 1\end{array}$ & 4 out of 4 & $\begin{array}{l}\text { Abruzzo } \\
\text { Region }\end{array}$ & Abruzzo Region & $\mathrm{x}$ & $x$ & $\mathrm{x}$ \\
\hline $\begin{array}{c}\text { Abruzzo } \\
\text { Region-Area } 2 \\
\end{array}$ & 5 out 5 & $\begin{array}{l}\text { Abruzzo } \\
\text { Region }\end{array}$ & Abruzzo Region & $\mathrm{x}$ & $x$ & $\mathrm{x}$ \\
\hline $\begin{array}{l}\text { Istrian Regional } \\
\text { Energy Agency } \\
\text { (IRENA) }\end{array}$ & 2 out of 3 & & $\begin{array}{c}\text { Istrian Regional Energy } \\
\text { Agency }\end{array}$ & $\mathrm{x}$ & $\mathrm{x}$ & $\mathrm{x}$ \\
\hline SDEWES Centre & 3 out of 5 & & SDEWES Centre & $\mathrm{x}$ & $\mathrm{x}$ & $x$ \\
\hline $\begin{array}{l}\text { Primorje-Gorski } \\
\text { Kotar County } \\
\text { (PGKC) }\end{array}$ & 4 out of 5 & & $\begin{array}{l}\text { Primorje-Gorsky Kotar } \\
\text { County }\end{array}$ & $\mathrm{x}$ & $x$ & $\mathrm{x}$ \\
\hline Split Dalmatia & 0 out of 8 & & $\begin{array}{l}\text { County of Split and } \\
\text { Dalmatia }\end{array}$ & $x$ & $x$ & $\mathrm{x}$ \\
\hline Vela Luka & 5 out of 5 & & Municipality of Vela Luka & $x$ & $x$ & $x$ \\
\hline
\end{tabular}

In particular, it should be noted that to prepare their SEAP, all municipalities in the Abruzzo Region were financed by the region through the Regional Operational Programme (ROP) under the European Regional Development Fund (ERDF). The Abruzzo Region, which in 2010 signed its membership in the CoM as Covenant Territorial Coordinator (CTC), also signed an agreement protocol that same year among the four Provinces constituting the region - the National Association of Italian Municipalities (ANCI) - intending to create a control centre to coordinate all the activities necessary for implementing the initiatives in the CoM. This commitment has been recognized by the European Commission as good practice to be disseminated and replicated [26]. The Abruzzo Region has therefore assumed a key role in raising awareness and involving administrations in its territory, also playing an important supporting role in the path from joining the CoM to the SEAP, particularly in finding the financial resources for drafting the Plan.

In Croatia, some municipalities in the pilot area of Vela Luka were supported in preparing their SEAP by the MESHARTILITY project (Measure and share data with utilities for the Covenant of Mayors) financed by the Intelligent Energy Europe Programme (IEE) [27].

With regard to coordination, unlike in Italy, a lack of CTCs can be seen in Croatia, as shown in Table 2. In the Joint_SECAP project, the Abruzzo Region plays the role of CTC and promotes two joint plans in two different pilot areas. 
As for the role of the coordinator/manager, the pilot areas were coordinated by the Joint_SECAP project partner identified as most important for technical, organizational, and administrative skills and more attentive to the climate issue.

An analysis of the Croatian cases shows that coordination of the plan drafting process is entrusted to regional agencies or international centres for sustainable energy or authorities that have also played a key role in raising awareness and strengthening the awareness of administrators and technicians on climate and energy issues. Processes tied to energy efficiency and the impacts of climate change are complex issues for municipalities that need planning based on collaboration and coordination between political and technical will, a multidisciplinary approach, and a systemic vision structured on interdisciplinary dialogue and cooperation between different sectors and offices $[22,28,29]$. As requested by the $\mathrm{CoM}$, the partners have created a working group in which political figures and technicians are jointly involved in the Joint_SECAP project. The political involvement optimizes the operation of internal structures by identifying and designating the appropriate skills and human resources and realizes actions for the community's involvement and participation.

The stakeholders involved in all phases include: organizations and offices within the municipalities; national, regional and local bodies; technical and administrative experts; professional associations, businesses, or locales; economic operators; and groups of citizens (see Section 3.3).

Table 2 shows that the partners to assess the potential needs have to involve administrative and technical sectors from the beginning and hire external experts with specific skills.

In all cases analysed, the promoters are supported during the process by external consultant companies that intervene to various degrees and with different methods in drafting the tool.

The external consultant companies were entrusted with supporting tasks for the risk and vulnerability analysis; the identification of indicators; the definition of joint actions and related analysis of consistency with the superordinate planning; the implementation of the participatory process for defining the optimal scenario; the definition of joint actions; and editing the plan.

From a careful analysis, the support of EU funds enables financing not only of the activities but also the process and governance of the project. In particular, these funds make specific steps more manageable and more feasible, such as the involvement of stakeholders and participation aimed at identifying scenarios and adaptation options, which would be more complicated to implement with ordinary funds.

\subsection{Synergies between the Risk and Vulnerability Assessment and Spatial Planning}

The Joint_SECAP drafting process, first of all, concerned the regulatory and planning framework on which the climatic scenarios and the RVA were based.

In general, several plans and programs on different administrative levels were used by the partners as a reference during development of the joint SECAPs.

Specific tools for adaptation to climate change were developed nationally with Adaptation Strategies and all the joint SECAPs refer to the national strategy. Only the Abruzzo Region refers to its regional territorial plan.

On the regional level, many plans deal with the identification of risk areas with extreme climate events (landslides, flooding, coastal erosion) and, in addition to defining the constraints and areas subject to protection, these tools for soil defence indicate intervention strategies and measures.

In Italy, another relevant planning level is the Province, with the Territorial Coordination Plans, while in Croatia, this planning level has been assimilated into the regional one. There are no local contexts in which specific plans for climate adaptation have been developed, except in the case of the Municipal Emergency Plans (PEC), which are drawn up for emergencies and natural disasters.

The project partners analysed strategies, objectives, and measures of these plans as a starting point to define actions and develop joint plans. 
In this sense, application of the SEA is certainly an innovative aspect of the Joint_SECAP method and the results of the experiences. Verification of external coherence made it possible to organize and align the objectives and strategies of the various tools on the national and local scales (Table 3).

Table 3. Questionnaire results for the RVA, participatory process, and SEA.

\begin{tabular}{|c|c|c|c|c|c|}
\hline \multicolumn{6}{|c|}{ Risk and Vulnerability Assessment and Participatory Process } \\
\hline \multirow[b]{2}{*}{$\begin{array}{c}\text { Partner Joint_SECAP } \\
\text { Project }\end{array}$} & Method & Data & SEA & Focus Groups & \multirow[b]{2}{*}{ Consultant } \\
\hline & $\begin{array}{l}\text { (Was It Easy to } \\
\text { Use?) }\end{array}$ & $\begin{array}{c}\text { (Were Climate } \\
\text { Data Sufficient?) }\end{array}$ & (Was It Useful?) & $\begin{array}{l}\text { (Was the FG } \\
\text { Formula } \\
\text { Successful?) }\end{array}$ & \\
\hline \multirow[b]{2}{*}{$\begin{array}{l}\text { San Benedetto del } \\
\text { Tronto }\end{array}$} & no & yes & yes & yes & \multirow[b]{2}{*}{ yes } \\
\hline & not easy to apply & $\begin{array}{l}\text { different sources } \\
\text { and level of detail }\end{array}$ & $\begin{array}{l}\text { more useful at the } \\
\text { beginning of the } \\
\text { planning process }\end{array}$ & & \\
\hline \multirow[b]{2}{*}{ Pescara } & yes & yes & yes & no & \multirow[b]{2}{*}{ yes } \\
\hline & not easy to apply & $\begin{array}{c}\text { scarce availability } \\
\text { of local climate } \\
\text { data }\end{array}$ & & $\begin{array}{c}\text { reduced } \\
\text { participation due } \\
\text { to the COVID-19 } \\
\text { pandemic }\end{array}$ & \\
\hline \multirow[b]{2}{*}{ Abruzzo Region } & yes & yes & yes & yes & \multirow[b]{2}{*}{ yes } \\
\hline & & $\begin{array}{c}\text { scarce availability } \\
\text { of some climate } \\
\text { data }\end{array}$ & $\begin{array}{l}\text { also useful for } \\
\text { supporting } \\
\text { decisions and } \\
\text { action selection }\end{array}$ & $\begin{array}{c}\text { difficulty in } \\
\text { obtaining specific } \\
\text { information from } \\
\text { stakeholders }\end{array}$ & \\
\hline \multirow[b]{2}{*}{$\begin{array}{c}\text { Istrian Regional } \\
\text { Energy Agency } \\
\text { (IRENA) }\end{array}$} & yes & yes & yes & yes & \multirow[b]{2}{*}{ yes } \\
\hline & & & $\begin{array}{l}\text { useful data for } \\
\text { defining the future } \\
\text { scenario }\end{array}$ & $\begin{array}{l}\text { scarce involvement } \\
\text { of regional, } \\
\text { national } \\
\text { authorities }\end{array}$ & \\
\hline \multirow[b]{2}{*}{ SDEWES Centre } & yes & no & yes & yes & \multirow[b]{2}{*}{ yes } \\
\hline & & $\begin{array}{c}\text { scarce availability } \\
\text { of local climate } \\
\text { data }\end{array}$ & $\begin{array}{l}\text { useful to find } \\
\text { inconsistencies } \\
\text { between SECAP } \\
\text { and other plans }\end{array}$ & & \\
\hline \multirow[b]{2}{*}{$\begin{array}{l}\text { Primorje-Gorski Kotar } \\
\text { County (PGKC) }\end{array}$} & yes & no & yes & yes & \multirow[b]{2}{*}{ yes } \\
\hline & & $\begin{array}{c}\text { scarce availability } \\
\text { of local climate } \\
\text { data }\end{array}$ & $\begin{array}{l}\text { useful but may } \\
\text { prolong times }\end{array}$ & & \\
\hline \multirow[b]{2}{*}{ Split Dalmatia } & yes & no & yes & yes & \multirow[b]{2}{*}{ yes } \\
\hline & & $\begin{array}{c}\text { scarce availability } \\
\text { of local climate } \\
\text { data }\end{array}$ & $\begin{array}{c}\text { not useful for } \\
\text { defining scenarios }\end{array}$ & $\begin{array}{l}\text { difficulty involving } \\
\text { stakeholders in the } \\
\text { SEA process }\end{array}$ & \\
\hline \multirow[b]{2}{*}{ Vela Luka } & yes & no & yes & yes & \multirow[b]{2}{*}{ yes } \\
\hline & & $\begin{array}{c}\text { scarce availability } \\
\text { of local climate } \\
\text { data }\end{array}$ & $\begin{array}{c}\text { not useful for } \\
\text { defining scenarios }\end{array}$ & $\begin{array}{l}\text { difficulty involving } \\
\text { stakeholders in the } \\
\text { SEA process }\end{array}$ & \\
\hline
\end{tabular}

A central topic that emerges from a comparison of the cases relates to the data used to define climate scenarios and the risk and vulnerability assessment (RVA) (Tables 3 and 4). Most data that form the basis for planning on all levels and defining climate scenarios are processed nationally by the Ministries of Government Agencies, both in Italy and Croatia. 
National climate data are also accessible in open data format and usually have a detail referring to macro climatic regions. With regard to downscaling these data and climate scenarios, it should be highlighted that in Croatia, the partners of the Interreg Joint_SECAP project reported a scarcity of data and information on the regional and local scales [24,25].

Table 4. The regulatory framework, dataset, and RVA in the Joint_SECAP project.

\begin{tabular}{|c|c|c|c|c|c|c|c|c|c|c|c|c|c|}
\hline \multirow{2}{*}{$\begin{array}{c}\text { Partner } \\
\text { Joint_SECAP } \\
\text { Project }\end{array}$} & \multicolumn{3}{|c|}{$\begin{array}{c}\text { Regulatory } \\
\text { Framework (n) }\end{array}$} & \multicolumn{3}{|c|}{ Dataset $^{1}$} & \multirow[t]{2}{*}{$\begin{array}{l}\text { Climate } \\
\text { Scenario }\end{array}$} & \multicolumn{6}{|c|}{ Risk and Vulnerability Assessment (RVA) } \\
\hline & $\mathbf{N}$ & $\mathbf{R}$ & $\mathbf{L}$ & $\mathbf{N}$ & $\mathbf{R}$ & $\mathbf{L}$ & & Method & $\begin{array}{l}\text { Hazard } \\
\text { Report }\end{array}$ & $\begin{array}{l}\text { Vulnerability } \\
\text { Report }\end{array}$ & $\begin{array}{l}\text { Hazard } \\
\text { Maps }\end{array}$ & $\begin{array}{c}\text { Vulnerability } \\
\text { Maps }\end{array}$ & GIS \\
\hline $\begin{array}{c}\text { San Benedetto } \\
\text { del Tronto }\end{array}$ & 4 & 5 & 5 & $\mathrm{x}$ & $\mathrm{x}$ & $x$ & $\mathrm{x}$ & $\begin{array}{l}\text { IPCC } \\
\text { AR5 }\end{array}$ & $x$ & $\mathrm{x}$ & $x$ & $\mathrm{x}$ & $x$ \\
\hline Pescara & 4 & 4 & 5 & $\mathrm{x}$ & $\mathrm{x}$ & & $x$ & $\begin{array}{l}\text { IPCC } \\
\text { AR5 }\end{array}$ & $x$ & $x$ & & & \\
\hline $\begin{array}{l}\text { Abruzzo Region- } \\
\text { Pilot Area } 1\end{array}$ & 6 & 8 & 12 & $\mathrm{x}$ & $\mathrm{x}$ & & $\mathrm{x}$ & $\begin{array}{l}\text { IPCC } \\
\text { AR5 }\end{array}$ & $\mathrm{x}$ & $\mathrm{x}$ & $\mathrm{x}$ & $\mathrm{x}$ & $\mathrm{x}$ \\
\hline $\begin{array}{l}\text { Abruzzo Region- } \\
\text { Pilot Area } 2\end{array}$ & 6 & 8 & 9 & $\mathrm{x}$ & $\mathrm{x}$ & & $x$ & $\begin{array}{l}\text { IPCC } \\
\text { AR5 }\end{array}$ & $x$ & $\mathrm{x}$ & $x$ & $x$ & $x$ \\
\hline $\begin{array}{c}\text { Istrian Regional } \\
\text { Energy Agency } \\
\text { (IRENA) }\end{array}$ & 7 & 3 & 4 & $\mathrm{x}$ & & & $x$ & $\begin{array}{l}\text { IPCC } \\
\text { AR5 }\end{array}$ & $x$ & $x$ & & $x$ & $x$ \\
\hline SDEWES Centre & 1 & 1 & 1 & $\mathrm{x}$ & & & & $\begin{array}{l}\text { IPCC } \\
\text { AR5 }\end{array}$ & $x$ & $x$ & $x$ & & \\
\hline $\begin{array}{l}\text { Primorje-Gorski } \\
\text { Kotar County } \\
\text { (PGKC) }\end{array}$ & 1 & 4 & 5 & $\mathrm{x}$ & & & $x$ & $\begin{array}{l}\text { IPCC } \\
\text { AR5 }\end{array}$ & $x$ & $x$ & & & \\
\hline Split Dalmatia & 4 & 4 & 4 & $x$ & $\mathrm{x}$ & & $x$ & $\begin{array}{l}\text { IPCC } \\
\text { AR5 }\end{array}$ & $x$ & $x$ & $x$ & $x$ & \\
\hline Vela Luka & 1 & 1 & 4 & $\mathrm{x}$ & $\mathrm{x}$ & & $x$ & $\begin{array}{l}\text { IPCC } \\
\text { AR5 }\end{array}$ & $x$ & $x$ & $x$ & $\mathrm{x}$ & \\
\hline
\end{tabular}

On the other hand, the Italian Regions have developed territorial information systems and databases structured on a rather widespread monitoring network managed by the Regional Agencies for Environmental Protection (ARPA).

In two of the cases in Italy (Abruzzo Region, San Benedetto del Tronto) and one in Croatia (IRENA), the administrations have developed local GISs and detailed climate scenarios.

The RVA was developed by each partner as a mandatory step in preparing the plan.

All partners in the Joint_SECAP project used the criteria and phases for the RVA based on the method defined by the Fifth Assessment Report by the Intergovernmental Panel on Climate Change (IPCC AR5) [30].

In general, the comparative analysis and questionnaires showed that the definition of the planning reference framework, collection of local and regional climate data, and development of the RVA were particularly complex and that the joint SECAP coordinators were supported by external experts and research centres with specific skills in climate planning and environmental assessment.

The comparison (Tables 3 and 4 ) on RVA for each pilot area, processed with external support, shows that:

- $\quad$ all of the SECAPs analysed contained a report of the hazards and vulnerabilities;

- two-thirds of the plans contain cartographic graphics and hazards maps, while less than half of them produced vulnerability maps;

- only in four pilot areas were risk maps prepared using GIS tools.

The comparison highlights that in more than $50 \%$ of cases, the RVA was processed without detailed regional or local data, and in some cases, the results are incomplete and 
lacking with regard to vulnerability. The lack of local data and the scarce use of GIS tools for their processing does not allow the most vulnerable areas to be represented and identified on the territory. The partners stated that to overcome the problem of the availability of local climate data, national databases were adapted to the local context with the support of external experts.

\subsection{The Involvement of Key Players and Stakeholders}

The key to implementing a SECAP in a concerted, coordinated way is the involvement of stakeholders starting from the initial phases of the development process: structuring the overall vision and defining the objectives and priorities for action. Their active involvement is the starting point for identifying and construction actions for adaptation. The Joint Research Centre guidelines [31] offer signatories a set of methodological and practical principles to develop a correct and fruitful participatory process for constructing adaptation scenarios and measures in response to climate hazards [32].

During implementation of the Interreg Joint_SECAP, the participatory process was initiated to actively involve stakeholders (Table 5) in identifying strategies and defining adaptation measures and actions to be implemented, starting from the results derived from the analysis and vulnerability-identification phase.

Table 5. Overview of stakeholder organizations.

\begin{tabular}{|c|c|c|c|c|c|c|}
\hline \multirow{3}{*}{ Partner Joint_SECAP Project } & \multicolumn{6}{|c|}{ Stakeholder } \\
\hline & \multicolumn{3}{|c|}{ Public Entities } & \multirow{2}{*}{ Academia } & \multirow{2}{*}{ NGO \& Civil Society } & \multirow{2}{*}{ Business \& Private Sector } \\
\hline & $\mathbf{N}$ & $\mathrm{T}$ & $\mathbf{L}$ & & & \\
\hline San Benedetto del Tronto & 2 & 5 & 5 & 2 & 4 & 1 \\
\hline Pescara & & & 5 & 1 & & \\
\hline Abruzzo Region-Pilot Area 1/Area 2 & 1 & 1 & 8 & & & 1 \\
\hline Istrian Regional Energy Agency (IRENA) & 1 & 1 & 4 & & & 2 \\
\hline SDEWES Centre & 2 & 3 & 3 & 1 & 1 & 4 \\
\hline Primorje-Gorski Kotar County (PGKC) & & 4 & 5 & & & 4 \\
\hline Split Dalmatia & & 1 & 5 & & & 3 \\
\hline Vela Luka & 1 & 3 & 5 & & 2 & 3 \\
\hline
\end{tabular}

To achieve this projection, each partner examined possible alternatives through a participatory process, choosing from among three possible participatory methods: EASW (European Awareness Scenario Workshop), expert panels, and focus groups [33-35]. The Joint_SECAP partners choose to use the focus group method by organizing thematic workshops in each pilot area with the commitment of important stakeholders and the activation of synergies and financial resources for joint actions on climate adaptation [36].

In total, 13 focus groups involved 237 participants. However, the total number of stakeholders consulted is larger, since many municipalities organized further consultations with important contacts (via email, phone calls, and interviews) [36].

The range of stakeholders was very wide: $42 \%$ of partners reported the involvement of local entities of the target areas, followed by territorial entities (19\%) and businesses and the private sector (19\%) (Table 5).

In total, during the focus groups, more than 250 measures were discussed, with the most important stakeholders in the target areas [36].

The aim of the Joint_SECAP focus groups was to discuss and propose potential climate change adaptation and mitigation measures by examining what would happen in the future on a defined timescale as mentioned above, to 2030. Starting from a series of factors that can be identified in the present and, in particular, using the VRAs made for each of the pilot areas, an option ' 0 ', or Scenario 0, describes the area's evolution if no attempt is made 
to intervene on vulnerabilities or risks. As an alternative, the participatory process led to a second option, namely 'optimal scenario', which aims to achieve the best possible environmental benefits through forecasting and the future implementation of adaptation measures.

For each pilot area, the partners selected a Joint Action Coordinator to coordinate activities on the district level, sharing procedures and objectives within the partnership. This coordinator is considered a new, relevant figure that was tested during the project to coordinate climate and energy measures on a wider territorial level, which is necessary for climate adaptation plans.

\subsection{Joint Actions for Adaptation on the Supra-Municipal Scale}

A series of single and joint mitigation and adaptation actions were identified; as explained in the objectives, only the joint adaptation actions are analysed here. The joint actions identified for each Italian and Croatian area highlighted the relationship between recurring hazards and the expected adaptation measures (Figure 3). From the number of joint measures envisaged for each climate hazard, it is possible to develop a general picture of the weight that each hazard exerts on each target area, leading to an understanding of the most common hazards in the Italian and Croatian territories. Actions for adaptation to climate change require purely local adaptation based on the identification of site-specific risks. They stem from applying the previously mentioned methodology (Figure 3) and information regarding the socioeconomic context and geographical-territorial and climatic features [37]. Adaptation options imply concrete actions to adjust to the actual or expected climate resulting from a range of suitable adaptation strategies and possibilities to address specific needs of the system [38]. These may encompass a wide range of alternatives that can be categorized as structural, institutional, or social [39].

Figure 3 shows just a partial picture of the possible actions implemented, since it refers only to joint actions. Even individual measures can clearly provide a decisive contribution and determine the weight in contrasting the effects of climate change in a specific territory.

The identified actions are calibrated to work in different sectors and tackle more than one hazard in other contexts. In particular, the analysis shows how intangible actions, i.e., those related to knowledge, data sharing, monitoring, training, and dissemination, can work simultaneously on different climate hazards. The idea of lumping different hazards together can hold concrete meaning if one envisages how often the impact chains develop as a combination of many factors [40,41]. Different climate hazards may have aspects in common, for example, they can occur in conjunction with the same climate event or intervene on specific vulnerabilities in a given territory. In particular, some territorial or urban vulnerabilities can contribute to the emergence of substantial climatic risks, or they can be boosted with the combination of several occurring hazards such as heavy precipitation, flooding, and droughts [32,42].

With regard to the measures in the Interreg Joint_SECAP project [24,43], the actions are described by responding more or less exhaustively to the standards of the Covenant of Mayors [44], reporting detailed information such as the implementing subjects, the subjects responsible, stakeholders, monitoring indicators, expected costs, and time frame.

Despite the different climate specifics of the territories, several climate hazards are recurring: floods, droughts, water scarcity and shortages, heatwaves and extreme temperatures, fires, landslides, and mass movements.

Within the plans analysed (Table 6), several intangible joint actions include:

1. events, systems, or IT platforms aimed at improving information or providing data on possible risks, along with communication, dissemination, and training. Early warning systems are present and refer to the possibilities offered by technological innovation [45], permitting the timely activation of action plans to minimize effects on people;

2. creation of inter-municipal bodies working on specific issues such as land consumption or water resource management; 
3. monitoring and data collection systems;

4. consultation and technical or financial assistance;

5. activation of associations or citizens' groups regarding specific issues such as the maintenance of green spaces.

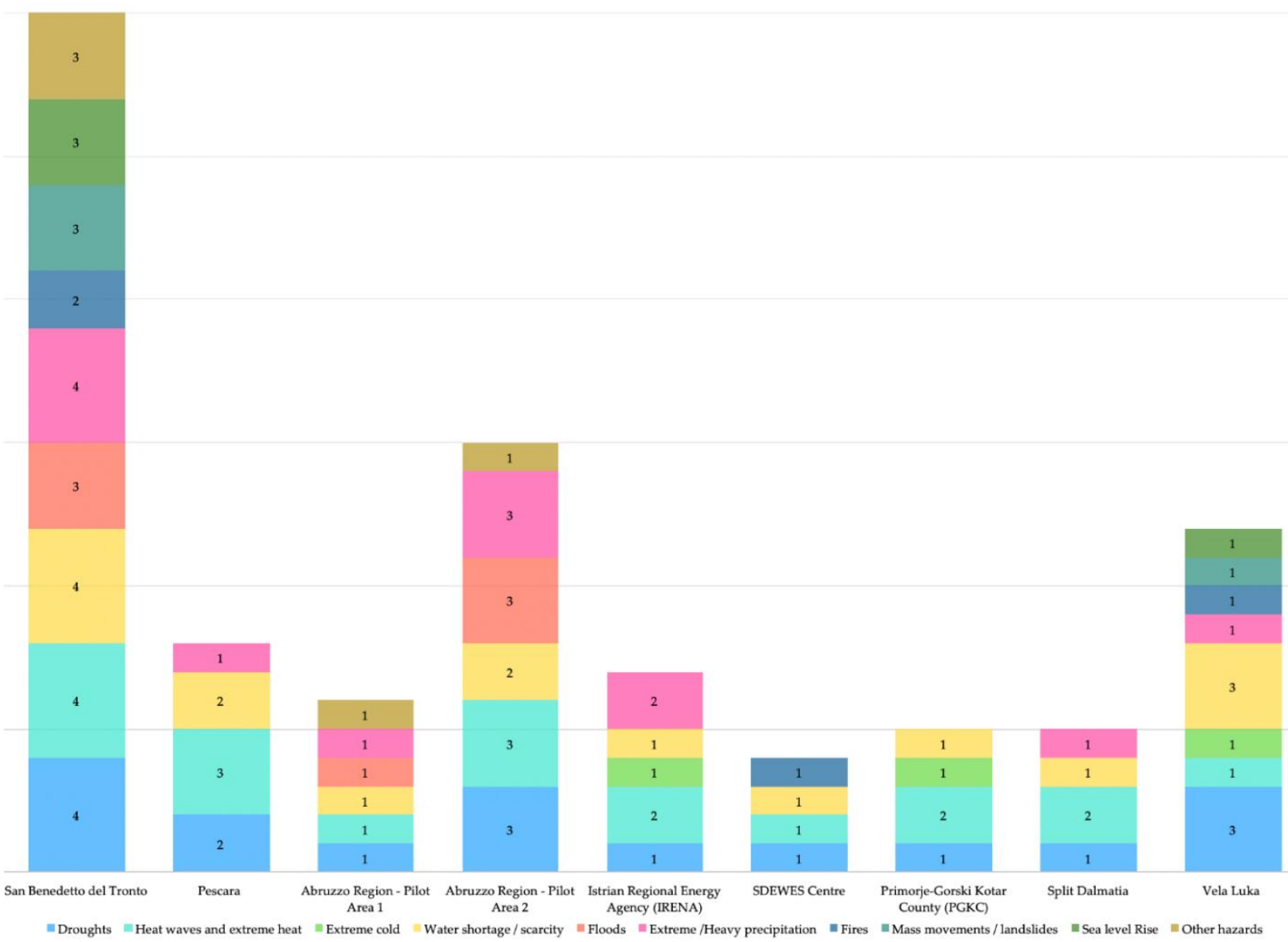

Figure 3. Recurring hazards and adaptation measures for each pilot area.

In particular, 50 joint actions were identified for all nine target areas: 32 for the Italian partners and 18 for Croatia, of which 47 are focused on adaptation [24,43]. These actions aim to reduce sensitivity and/or exposure to climate change or enhance adaptive capacity; they therefore include different behavioural, structural, and technological adjustments.

Soft, often flexible actions that can be implemented with limited budgets represent the majority of those selected and include the application of policies and procedures, information systems, land-use control, information dissemination, and economic incentives to reduce vulnerability, encourage adaptive behaviour, or avoid maladaptation. These actions include:

1. creating information (data collection and monitoring, raising awareness);

2. supportive social structures (e.g., organizational development, working in partnership, institutions);

3. supportive governance (regulations, legislation, and guidance).

Examples of green joint actions include vegetation, forestation, woodland management, increased landscape coverage, renaturalization of water bodies, and the creation of green shelters for protection from atmospheric events. 
Table 6. Number of tangible and intangible actions per pilot area.

\begin{tabular}{|c|c|c|c|c|}
\hline Joint_SECAP & $\begin{array}{l}\text { Tangible } \\
\text { Actions }\end{array}$ & $\begin{array}{c}\text { Intangible } \\
\text { Actions }\end{array}$ & $\begin{array}{c}\text { Number of } \\
\text { Joint } \\
\text { Actions } \\
\text { Analysed }\end{array}$ & $\begin{array}{c}\text { Intangible } \\
\text { Actions for } \\
\text { Multiple } \\
\text { Hazards }\end{array}$ \\
\hline San Benedetto del Tronto & 1 & 4 & 5 & 5 \\
\hline Pescara & 2 & 4 & 6 & 1 \\
\hline Abruzzo Region-Pilot Area 1 & & 8 & 8 & 5 \\
\hline Abruzzo Region-Pilot Area 2 & 4 & 9 & 13 & 8 \\
\hline $\begin{array}{l}\text { Istrian Regional Energy Agency } \\
\text { (IRENA) }\end{array}$ & 1 & 2 & 3 & 3 \\
\hline SDEWES Centre & 3 & & 3 & 2 \\
\hline $\begin{array}{c}\text { Primorje-Gorski Kotar County } \\
\text { (PGKC) }\end{array}$ & 1 & 2 & 3 & 3 \\
\hline Split Dalmatia-Pilot Area & 1 & 2 & 3 & 2 \\
\hline Vela Luka-Pilot Area & 1 & 2 & 3 & 1 \\
\hline
\end{tabular}

Grey joint actions include any new or improved complex physical infrastructure aimed at providing direct or indirect protection from climate hazards:

1. structural interventions aimed at reducing hydraulic risks and the creation of detention basins;

2. reconstruction of the water supply networks;

3. reinforcement and maintenance of cycling paths;

4. construction of mini and micro reservoirs for irrigation;

5. improvement of sewage systems.

The sectors most mentioned among the joint actions are agriculture, water supply, tourism, civil protection, and health.

Most actions are financed by a combination of different funding sources, meaning that neighbouring municipalities often need to cooperate in order to bundle together adaptation projects to make them bankable. Several actions are based on governmental (grants, international and EU funding, national, regional, and local budgets) and private (foundations, real estate developers, companies) funding sources. Public-private and private partnerships were chosen only by the Abruzzo Region and of San Benedetto del Tronto.

\section{Conclusions}

The analysis and comparison of the nine case studies in the Joint_SECAP project confirm that the joint climate planning developed within the framework of the CoM urban adaptation tool is effective for creating synergy between local entities and defining and implementing local adaptation projects and actions. The joint SECAP is the result of collaborative governance in which the involvement of stakeholders and key players is essential in all phases of the process.

The comparison of the case studies shows that the governance process is facilitated and more effective in cases where:

- the municipalities are aware of CoM activities and have already prepared or addressed a SEAP or SECAP, or where they have already acquired climate planning awareness;

- the bodies involved have already experienced collaborations in planning and programming tools on the supra-local scale;

- there is a Covenant Territorial Coordinator who provides support to local authorities;

The comparative analysis of experiences confirms that collaborative governance processes are complex, expensive, and time-consuming, so it is necessary to dedicate specific 
resources to their development. Local and regional entities involved in the Joint_SECAP project had access to non-ordinary funds through Interreg Italy-Croatia; however, to make this model replicable and sustainable, national and regional authorities should allocate specific resources to governance and, in particular, to joint planning processes.

In this context, the role of the coordinator/promoter is essential for developing and managing the entire plan drafting process. The research underlines that coordination structures should be strengthened and should carry out capacity-building activities, especially regarding new adaptations to climate change.

The research shows that another relevant aspect of collaborative climate planning is the ability to share information and knowledge among the various sectors of the local authorities involved. The criticalities that emerged in this activation phase of the process concern:

- the availability, reliability, and homogeneity of data and climate scenarios;

- the lack of skills and resources to develop the cognitive framework and RVA consistently with methods recognized on the European level.

The construction of the shared knowledge framework, climate scenarios, and the RVA in SMSTs still represents a challenge, since local authorities usually do not have the technical skills required to collect and process climate data. This paper highlights the central role of external consultants and research centres, not only in processing the climate data, but also in developing intervention scenarios.

A possible solution to overcome these difficulties is the creation of databases and climate scenarios, which could be managed regionally. Identifying ways to scale down from the national to the regional level and providing local administrations with data and tools to map hazards and risks may be beneficial. In this sense, the Regions and Provinces in Italy and the Counties and Energy Agencies in Croatia could play a key role in adaptation, providing vulnerability and risk data, indicators, and maps. In general, it is necessary to encourage state-regional synergies in climate planning and strengthen the flow of data and knowledge on the local level.

An innovative aspect of the Joint_SECAP project was the application of the internal and external coherence analyses of the SEA in the drafting phase of the action plan. Application of the SEA made it possible to bring the various territorial planning tools into line with the joint plan. It also facilitated horizontal and vertical collaboration between the various sectors of the entities involved and the construction of a complete and updated knowledge framework.

A second innovative aspect related to the Joint_SECAP project is the introduction of the Joint Coordinator, a central figure in the process who must encourage community involvement through a continuous learning and empowering process. In addition to the difficult role of connecting different entities, the Joint Coordinator should implement measures to orient joint SECAP developments over time, promoting new common actions and intercepting financing from various sources.

With reference to the joint actions identified during the participatory process aimed at identifying the optimal scenario, the partners identified a set of measures, particularly soft ones, which could be implemented with limited budgets but with careful management of the human systems. These actions correspond to the design and application of policies and procedures, land-use controls, information dissemination and economic incentives to reduce vulnerability, encourage adaptive behaviour, or avoid maladaptation. Some of these may facilitate the implementation of grey or green measures.

Starting with the results of the Joint_SECAP project, the prospects for future research should be oriented both towards financing mechanisms for joint actions and methods to implement and manage these actions in a context of collaboration between public and private actors.

To deepen the potential of the collaborative joint climate planning outlined above, however, other experimental experiences are necessary, even in different geographical 
and political-administrative contexts, which would account for the variability of local conditions.

Author Contributions: Conceptualization, T.D.B., S.M. (Stefano Magaudda) and P.P.; methodology, T.D.B., S.M. (Stefano Magaudda) and P.P.; formal analysis, T.D.B., C.C., S.M. (Stefano Magaudda), S.M. (Stefano Mugnoz) and P.P.; investigation, T.D.B., S.M. (Stefano Magaudda) and P.P.; data curation, T.D.B., S.M. (Stefano Magaudda), S.M. (Stefano Mugnoz) and P.P.; writing (original draft preparation), T.D.B., C.C., S.M. (Stefano Magaudda), S.M. (Stefano Mugnoz) and P.P.; writing (review and editing), T.D.B., S.M. (Stefano Mugnoz) and P.P.; visualization, T.D.B. and P.P.; supervision, T.D.B., S.M. (Stefano Magaudda), S.M. (Stefano Mugnoz) and P.P. All authors have read and agreed to the published version of the manuscript.

Funding: This research was funded by 'Joint_SECAP-Joint strategies for Climate Change Adaptation in coastal areas'-Project 2014-2020 INTERREG V-A Italy-Croatia CBC Programme, grant number 10047506.

Data Availability Statement: The data used refer to the Joint_SECAP project's deliverables as reported in the references section.

Conflicts of Interest: The authors declare no conflict of interest.

$\begin{array}{ll}\text { Abbreviations } \\ \text { List of abbreviations including units and nomenclature } \\ \text { ANCI } & \text { National Association of Italian Municipalities } \\ \text { ARPA } & \text { Regional Agencies for Environmental Protection } \\ \text { CoM } & \text { Covenant of Mayors } \\ \text { CTC } & \text { Covenant Territorial Coordinator } \\ \text { EC } & \text { European Commission } \\ \text { EU } & \text { European Union } \\ \text { ERDF } & \text { European Regional Development Fund } \\ \text { GIS } & \text { Geographic information system } \\ \text { IEE } & \text { Intelligent Energy Europe Programme } \\ \text { IPCC } & \text { Intergovernmental Panel on Climate Change } \\ \text { IRENA } & \text { Istrian Regional Energy Agency } \\ \text { L } & \text { Local level } \\ \text { N } & \text { National level } \\ \text { NGO } & \text { Non-governmental organization } \\ \text { NUTS } & \text { Nomenclature of Territorial Units for Statistics } \\ \text { PA } & \text { Public Administration } \\ \text { PEC } & \text { Municipal Emergency Plan } \\ \text { R } & \text { Regional Level } \\ \text { ROP } & \text { Regional Operational Programme } \\ \text { RVA } & \text { Risk and vulnerability assessment } \\ \text { SDEWES } & \text { Centre International Centre for Sustainable Development of Energy, } \\ \text { PGKC } & \text { Water and Environment Systems } \\ \text { SEA } & \text { Primorje-Gorski Kotar County } \\ \text { SEAP } & \text { Strategic Environmental Assessment } \\ \text { SECAP } & \text { Sustainable Energy and Climate Action Plan } \\ \text { SMSTs } & \text { Small and medium-sized towns } \\ \text { T } & \text { Territorial Level } \\ \end{array}$

\section{References}

1. UE 2021 Strategy on Adaptation. 2021. Available online: https:/ /ec.europa.eu/clima/eu-action/adaptation-climate-change/euadaptation-strategy_it (accessed on 22 November 2021).

2. Covenant of Mayors Website. Available online: https://www.covenantofmayors.eu/en/ (accessed on 26 November 2021).

3. Bertoldi, P.; Rivas, S.; Kona, A.; Hernandez, Y.; Barbos, P.; Palermo, V.; Baldi, M.; Lo Vullo, E.; Muntean, M. Covenant of Mayors: 2019 Assessment. In JRC Science for Policy Report; Publications Office of the European Union: Luxembourg, 2020; ISBN 978-92-76-10722-4. 
4. Scorza, F.; Santopietro, L. A Systemic Perspective for the Sustainable Energy and Climate Action Plan (SECAP). Eur. Plan. Stud. 2021, 1-21. [CrossRef]

5. Covenant of Mayors for Climate \& Energy Office. Quick Reference Guide Joint Sustainable Energy \& Climate Action Plan. 2017 Available online: https:/ / www.covenantofmayors.eu/support/reporting.html (accessed on 26 November 2021).

6. Musco, F. Postfazione. In Emergenza Clima e Qualità della Vita nelle Città; Brownlee, T.D., Camaioni, C., Pellegrino, P., Eds.; Franco Angeli: Milan, Italy, 2021; ISBN 978-88-351-0907-5.

7. Santopietro, L.; Scorza, F. The Italian Experience of the Covenant of Mayors: A Territorial Evaluation. Sustainability 2021, 13, 1289. [CrossRef]

8. Karrasch, L.; Maier, M.; Kleyer, M.; Klenke, T. Collaborative Landscape Planning: Co-Design of Ecosystem-Based Land Management Scenarios. Sustainability 2017, 9, 1668. [CrossRef]

9. Abarca-Alvarez, F.J.; Navarro-Ligero, M.L.; Valenzuela-Montes, L.M.; Campos-Sánchez, F.S. European Strategies for Adaptation to Climate Change with the Mayors Adapt Initiative by Self-Organizing Maps. Appl. Sci. 2019, 9, 3859. [CrossRef]

10. Flyen, C.; Lappegard Hauge, A.; Almås, A.; Lund Godbolt, Å.L. Municipal Collaborative Planning Boosting Climate Resilience in the Built Environment. Int. J. Disaster Resil. Built Environ. 2018, 9, 58-69, ISSN 1759-590. [CrossRef]

11. Uittenbroek, C.; Leonie, B.; Janssen-Jansen, L.B.; Runhaar, H.A.C. Mainstreaming Climate Adaptation into Urban Planning: Overcoming Barriers, Seizing Opportunities and Evaluating the Results in Two Dutch Case Studies. Reg. Environ. Chang. 2013, 13, 399-411. [CrossRef]

12. Owen, G. What Makes Climate Change Adaptation Effective? A Systematic Review of the Literature. Glob. Environ. Chang. 2020, 62, 102071. [CrossRef]

13. Messori, G.; Brocchieri, F.; Morello, E.; Ozgen, S.; Caserini, S. A Climate Mitigation Action Index at the Local Scale: Methodology and Case Study. J. Environ. Manag. 2020, 260, 110024, ISSN 0301-4797. [CrossRef] [PubMed]

14. De Pascali, P.; Bagaini, A. L'affermazione del PIANO D'azione per L'energia Sostenibile (PAES) in Italia. Limiti e tentativi di Integrazione Con la Pianificazione Locale. Archivio Di Studi Urbani E Regionali 2021, 131, 2021. [CrossRef]

15. Melica, G.; Bertoldi, P.; Kona, A.; Iancu, A.; Rivas, S.; Zancanella, P. Multilevel Governance of Sustainable Energy Policies: The Role of Regions and Provinces to Support the Participation of Small Local Authorities in the Covenant of Mayors. Sustain. Cities Soc. 2018, 39, 729-739. [CrossRef]

16. Pietrapertosa, F.; Salvia, M.; De Gregorio Hurtado, S.; D’Alonzo, V.; Church, J.M.; Geneletti, D.; Musco, F.; Reckien, D. Urban Climate Change Mitigation and Adaptation Planning: Are Italian Cities Ready? Cities 2019, 91, 93-105, ISSN 0264-2751. [CrossRef]

17. Haupt, W. European Municipalities Engaging in Climate Change Mitigation and Adaptation Networks: Examining the Case of the Covenant of Mayors. In Resilience-Oriented Urban Planning. Lecture Notes in Energy; Yamagata, Y., Sharifi, A., Eds.; Springer: Berlin/Heidelberg, Germany, 2018; Volume 65. [CrossRef]

18. Jekabsone, A.; Marín, J.; Martins, S.; Rosa, M.; Kamenders, A. Upgrade from SEAP to SECAP: Experience of 6 European Municipalities. Environ. Clim. Technol. 2021, 25, 254-264. [CrossRef]

19. ENEA. Rapporto Annuale Efficienza Energetica 2019. Agenzia Naz. Nuove Tecnol. L'Energia Svilupp. Econ. Sostenibile 2019, 175-179. Available online: https://www.enea.it/it/seguici/pubblicazioni/pdf-volumi/2019/raee-2019.pdf (accessed on 12 December 2021).

20. Pietrapertosa, F.; Salvia, M.; De Gregorio Hurtado, S.; Geneletti, D.; D'Alonzo, V.; Reckien, D. Multi-Level Climate Change Planning: An Analysis of the Italian Case. J. Environ. Manag. 2021, 289, 112469. [CrossRef] [PubMed]

21. Palermo, V.; Hernandez, Y. Group Discussions on How to Implement a Participatory Process in Climate Adaptation Planning: A Case Study in Malaysia. Ecol. Econ. 2020, 177, 106791. [CrossRef] [PubMed]

22. Magni, F.; Musco, F.; Litt, G.; Carraretto, G. The Mainstreaming of NBS in the SECAP of San Donà di Piave: The LIFE Master Adapt Methodology. Sustainability 2020, 12, 10080. [CrossRef]

23. Yin, R.K. Case Study Research. In Design and Methods; Sage: Thousand Oaks, CA, USA, 1994.

24. Interreg Italy-Croazia Joint-SECAP Official Website. Available online: https://www.italy-croatia.eu/web/jointsecap (accessed on 7 May 2021).

25. Interreg Joint_SECAP Support System Platform. Available online: https:/ /joint-secap.unicam.it/ (accessed on 11 June 2021).

26. AbruzzoRegion. Patto dei Sindaci. Available online: https://www.regione.abruzzo.it/content/patto-dei-sindaci (accessed on 11 June 2021)

27. Covenant of Mayors, News: Improving the Collection and Access to Energy Data: Recommendations from the Meshartility Project. Available online: https:/ / eumayors.eu/news-and-events/news/1297-improving-the-collection-and-access-to-energydata-recommendations-from-the-meshartility-project.html (accessed on 26 November 2021).

28. Brownlee, T.D.; Camaioni, C.; Pellegrino, P. Governance dei Rischi e Delle Vulnerabilità per L'adattamento ai Cambiamenti Climatici Nelle Aree Costiere. Il Progetto Interreg Italia-Croazia Joint_Secap; XII Giornata Internazionale di Studio INU Benessere e/o Salute? 90 Anni di Studi, Politiche, Piani, Urbanistica e Informazione Special Issue 289s.i; Moccia, F.D., Sepe, M., Eds.; INU: Roma, Italy, 2020; ISSN 0392-5005; Available online: http:/ / www.urbanisticainformazioni.it/IMG/pdf/ui289si_sessione_speciale_8.pdf (accessed on 26 November 2021)ISSN 0392-5005.

29. Pellegrino, P. Il Passaggio dal PAES al PAESC: Scenari Energetici e Clima-Adattivi Nella Pianificazione delle Aree Costiere. ASUR 2021, 131, 97-117. [CrossRef] 
30. IPCC. Climate Change 2014: Synthesis Report. Contribution of Working Groups I, II and III to the Fifth Assessment Report of the Intergovernmental Panel on Climate Change; IPCC: Geneva, Switzerland, 2014; Available online: https://www.ipcc.ch/site/assets/ uploads/2018/02/SYR_AR5_FINAL_full.pdf (accessed on 11 June 2021).

31. Bertoldi, P. Guideline How to Develop a Sustainable Energy and Climate Action Plan (SECAP). Part 1-The SECAP Process, Step-by-Step towards Low Carbon and Climate Resilient Cities by 2030; Publications Office of the European Union: Luxembourg, 2018; ISBN 978-92-79-96847-1.

32. Skilodimou, H.D.; Bathrellos, G.D. Natural and Technological Hazards in Urban Areas: Assessment, Planning and Solutions. Sustainability 2021, 13, 8301. [CrossRef]

33. Jäger, C. Focus Groups in Integrated Assessment: A Manual for Participatory Research. In ULYSSES Working Paper; WP-97-2; Center for Interdisciplinary Studies in Technology, Darmstadt University of Technology: Darmstadt, Germany, 1997.

34. Ochieng, N.T.; Wilson, K.; Derrick, C.J.; Mukherjee, N. The Use of Focus Group Discussion Methodology: Insights from Two Decades of Application in Conservation. Methods Ecol. Evol. 2018, 9, 20-32. [CrossRef]

35. Slocun, M. Participatory Methods Toolkit: A Practitioner's Manual; Steyaert, S., Ed.; King Baudouin Foundation: Brussels, Belgium, 2003; Available online: https:/ / archive.unu.edu/hq/library/Collection/PDF_files/CRIS/PMT.pdf (accessed on 11 June 2021).

36. Interreg Joint_SECAP. Deliverable 4.1.2, Joint Thematic Focus Group Report, Joint_SECAP Project. Available online: https: / / joint-secap.unicam.it/node/10 (accessed on 11 June 2021).

37. Brownlee, T. L'Adattamento ai Cambiamenti Climatici negli Spazi Aperti Urbani, Nuove Sfide e Opportunità. In Emergenza Clima e Qualità della Vita nelle Città; Brownlee, T.D., Camaioni, C., Pellegrino, P., Eds.; Franco Angeli: Milano, Italy, 2021; ISBN 978-88-351-0907-5.

38. Delgado Marín, J.P.; Meseguer, P. Guide for the elaboration of Sustainable Energy and Climate Action Plans. 2019. Available online: https:/ / lifeadaptate.eu/wp-content/uploads/LIFE-Adaptate-SECAP-Guide.pdf (accessed on 11 June 2021).

39. IPCC. Annexe I. In Global Warming of $1.5^{\circ} \mathrm{C}$. An IPCC Special Report on the Impacts of Global Warming of $1.5^{\circ} \mathrm{C}$ above Pre-Industrial Levels and Related Global Greenhouse Gas Emission Pathways, in the Context of Strengthening the Global Response to the Threat of Climate Change, Sustainable Development, and Efforts to Eradicate Poverty; Masson-Delmotte, V., Zhai, P., Pörtner, H.O., Roberts, D., Skea, J., Shukla, P.R., Pirani, A., Moufouma-Okia, W., Péan, C., Pidcock, R., et al., Eds.; IPCC: Geneva, Switzerland, 2018; Available online: https:/ / www.ipcc.ch/sr15/chapter/glossary/ (accessed on 11 June 2021).

40. GIZ and EURAC. Risk Supplement to the Vulnerability Sourcebook. In Guidance on How to Apply the Vulnerability Sourcebook's Approach with the New IPCC AR5 Concept of Climate Risk; GIZ: Bonn, Germany, 2017.

41. Hagenlocher, M.; Schneiderbauer, S.; Sebesvari, Z.; Bertram, M.; Renner, K.; Renaud, F.; Wiley, H.; Zebisch, M. Climate Risk Assessment for Ecosystem-based Adaptation. In A Guidebook for Planners and Practitioners; Deutsche Gesellschaft für Internationale Zusammenarbeit (GIZ) GmbH: Bonn, Germany, 2018.

42. Matos Silva, M. Public Spaces for Water: A Design Notebook; CRC Press: Boca Raton, FL, USA, 2019.

43. Interreg Joint_SECAP. Deliverable 4.3, Joint Actions Implementation. Available online: https://joint-secap.unicam.it/node/10 (accessed on 11 June 2021).

44. Covenant of Mayors for Climate \& Energy Office. The Covenant of Mayors for Climate and Energy Reporting Guidelines. 2016. Available online: https:/ / www.covenantofmayors.eu/IMG/pdf/Covenant_ReportingGuidelines.pdf (accessed on 11 June 2021).

45. Linares, C.; Martinez, G.S.; Kendrovski, V.; Diaz, J. A New Integrative Perspective on Early Warning Systems for Health in the Context of Climate Change. Environ. Res. 2020, 187, 109623. [CrossRef] [PubMed] 